\title{
Keefektifan Penggunaan Metode Clustering dan Show Not Tell terhadap Kemampuan Menulis Teks Deskripsi Peserta Didik SMP Kelas VII di Kecamatan Binamu Kabupaten Jeneponto
}

\author{
Iskandar ${ }^{1}$ \\ Munirah $^{2}$ \\ Sitti Aida Asis ${ }^{3}$
}

\section{1,2,3 Magister Pendidikan Bahasa dan Sastra Indonesia, Universitas Muhammadiyah Makassar}

andhalusia.anda@gmail.com ${ }^{1}$

munirah@unismuh.ac.id ${ }^{2}$

fkipida@gmail.com³

\begin{abstract}
Abstrak
Desain yang digunakan adalah one group pretest-posttest design, yaitu desain penelitian yang diberikan pre-test sebelum diberikan perlakuan dan pemberian post-test setelah diberikan perlakuan atau tindakan. Populasi dalam penelitian ini adalah SMP Negeri seKecamatan Binamu yang berjumlah 9 sekolah. Sampel dalam penelitian ini sebanyak 3 kelas pada tiga sekolah dengan jumlah 75 peserta didik. Penarikan sampel dilakukan dengan cara random cluster sampling. Dalam penelitian ini yang menjadi sampel adalah SMP Negeri 9 Binamu sebanyak 33 peserta didik, 27 Peserta didik di SMPN 6 Binamu, dan 25 Peserta didik di SMPN 4 Binamu. Jadi, jumlah keseluruhan peserta didik pada 3 sekolah sebanyak 75 peserta didik. Data yang diperoleh dianalisis dengan statistik deskriptif kuantitatif dan statistik inferensial. Hasil analisis statistik deskriptif kuantitiatif menunjukkan bahwa penggunaan metode clustering dan Show Not Tell efektif dalam pembelajaran menulis teks deskripsi peserta didik SMP kelas VII di Kecamatan Binamu. Hal ini dibuktikan berdasarkan perolehan nilai rata-rata peserta didik pada pre-test 35,62. Selanjutnya, nilai post-test diperoleh nilai rata-rata sebesar 72,24 dengan jumlah sampel sama dengan pretest sebanyak 75 . Berdasarkan data statistik tersebut menunjukkan bahwa terjadi peningkatan nilai rata-rata hasil penilaian menulis peserta didik berdasarkan nilai pre-test dan nilai post-test. Hasil analisis inferensial menggunakan uji $t$ model paired sampel test tampak bahwa penggunaan metode clustering dan Show Not Tell efektif diterapkan dalam pembelajran menulis teks deskripsi pada peserta didik SMP kelas VII di Kecamatan Binamu. Selain itu, diperoleh nilai Sig. ( 2 tailed) sebesar $0,000<0,05$. Ini menunjukkan bahwa terdapat perbedaan yang nyata hasil penilaian menulis teks deskripsi sebelum (pre-test) dan setelah (posttest) menggunakan metode Clustering dan Show Not Tell.
\end{abstract}

Kata Kunci: Menulis Teks Deskripsi, Clustering, Show Not Tell

\section{Pendahuluan}

Pelajaran bahasa Indonesia berorientasi pada hakikat pembelajaran bahasa, yakni belajar bahasa adalah belajar berkomunikasi dan belajar sastra adalah belajar menghargai manusia dan nilai-nilai kemanusiaannya. Oleh karena itu, Dalam kurikulum 2013 pada aspek pengetahuan dan keterampilan, kompetensi pembelajaran bahasa Indonesia diarahkan untuk meningkatkan kemampuan peserta didik untuk 
berkomunikasi dalam bahasa Indonesia, baik secara lisan maupun tertulis serta menimbulkan penghargaan terhadap hasil cipta manusia Indonesia. Pada pelajaran bahasa Indonesia di sekolah, empat aspek berbahasa harus mampu peserta didik kuasai setelah menjalani proses kegiatan belajar mengajar. Akan tetapi, dalam aspek keterampilan menulis dibutuhkan suatu strategi atau metode yang tepat sehingga dalam menuangkan gagasan dan ide ke dalam tulisan, peserta didik dapat melakukannya dengan baik.

Sekaitan dengan hal tersebut, mata pelajaran bahasa Indonesia pada Kurikulum 2013 berdasarkan Permendikbud Nomor 24 Tahun 2016 terdapat kompetensi dasar yang menekankan pada kemampuan menulis peserta didik. Kompetensi yang dimaksud terdapat pada Kompetensi Inti 4 yakni mencoba, mengolah, dan menyaji dalam ranah konkret dan ranah abstrak sesuai dengan yang dipelajari di sekolah dan sumber lain yang sama dalam sudut pandang/teori.

Salah satu kompetensi dasar yang menekankan pada keterampilan menulis tertuang dalam kompetensi dasar 4.2, yakni menyajikan data, gagasan, kesan dalam bentuk teks deskripsi tentang objek secara tulis dan lisan dengan memperhatikan struktur, kebahasaan baik secara lisan maupun tulis . Dalam hal ini, pencapaian yang dimaksud adalah peserta didik diharapkan mampu menyajikan data, gagasan, kesan, dan perasaan dalam bentuk teks deskripsi.

Menurut Gie (Lestari 2009:201) tulisan dapat digolongkan menjadi beberapa jenis berdasarkan kriteria tertentu. Berdasarkan bentuknya, tulisan dapat digolongkan menjadi: cerita , lukisan, paparan dan bincangan.Dalam penelitian ini, objek yang menjadi kajian adalah karangan deskripsi. Pembelajaran menulis khususnya deskripsi yang dimaksud di sini adalah teks atau karangan yang menggambarkan sesuatu sesuai dengan objeknya agar pembaca seolah-olah melihat, merasakan, dan mendengar objek yang diuraikan oleh penulis.

Jika dalam kegiatan berbicara orang harus menguasai lambang-lambang bunyi maka dalam kegiatan menulis orang harus menguasai lambang atau simbol-simbol visual dan aturan tata tulis, khususnya yang menyangkut masalah ejaan. Agar komunikasi dalam lambang tulis dapat seperti yang diharapkan, penulis hendaknya menuangkan gagasan ke dalam bahasa yang tepat, teratur, dan lengkap (Asniar 2019:2). Dalam hubungan ini, sering kita dengar adanya kata-kata: bahasa yang teratur merupakan manifestasi pikiran yang teratur pula.. Dibanding tiga kemampuan berbahasa yang lain, kemampuan menulis lebih sulit dikuasai bahkan oleh penutur asli suatu bahasa itu sendiri. Hal itu disebakan kemampuan menulis menghendaki penggunaan berbagai unsur kebahasaan dan di luar unsur bahasa yang menjadi isi karangan. Baik unsur bahasa maupun unsur isi haruslah terjalin sedemikian rupa sehingga menghasilkan karangan yang runtut dan padu.

Pelajaran menulis pada umumnya menjadi momok bagi peserta didik lantaran pengelolaan pembelajaran yang kurang menarik, efektif dan efisien (Kurniawan dan Kartini 2019:34). . Selanjutnya, Nurgiyantoro (dalam Heri, 2015: 9-10) juga menyatakan jika dibandingkan dengan keterampilan berbahasa yang lain, keterampilan menulis lebih sulit dikuasai oleh pembelajar bahasa. Hal tersebut karena, keterampilan berbahasa menghendaki penguasaan berbagai aspek lain diluar bahasa untuk menghasilkan karangan yang padu dan utuh.

Kemampuan menulis membutuhkan perhatian khusus dalam pembelajaran bahasa Indonesia. Kemampuan menulis karangan tidak akan terjadi dengan sendirinya, tetapi memerlukan pembinaan dan latihan terus menerus, berkesinambungan, dan dilakukan sebagai proses pengembangan (Munirah 2017:152). Selain hal tersebut, untuk menghasilkan tulisan yang baik, dituntut beberapa kemampuan, yakni pengetahuan 
tentang apakah yang akan ditulis, dan bagaimana menuliskannnya. Pengetahuan menyangkut isi karangan dan menyakut aspek kebahasaan dan teknik penulisan. Baik isi karangan, aspek kebahasaan maupun teknik penulisan bertalian erat dengan proses berpikir.

Kenyataan di lapangan menunjukkan bahwa pembelajaran menulis di SMP belum mencapai hasil yang diinginkan. Kemudian, dilanjutkan pemberian tugas kepada peserta didik untuk membuat karangan yang dikehendaki. Kegiatan peserta didik pada proses pembelajaran atau proses penulisan, baik dari tahap pramenulis sampai pada tahap penulisan kurang dan bahkan tidak mendapat perhatian. Hal ini sejalan dengan pendapat Munirah (2019:152) mengatakan bahwa pembelajaran menulis yang dilakukan pengajar masih mengedepankan hasil dan belum pada proses menulis.

Berdasarkan observasi awal yang dilakukan, hal ini menyulitkan peserta didik bahkan tidak mampu untuk memulai tulisan. Akibatnya, kemampuan menulis peserta didik tidak dapat mencapai sasaran seperti yang diharapakan sehingga kemampuan menulis peserta didik masih rendah, dibutuhkan suatu strategi atau metode untuk meningkatkan kemampuan menulis peserta didik, terkhusus peserta didik kelas VII SMP yang masih tahap pemula.

Beberapa penelitian terdahulu tentang menulis yang relevan dengan penelitian ini, yaitu Keefektivan Strategi Brainstorming dalam Pembelajaran Menulis Paragraf Argumentasi pada Peserta didik Kelas XI SMA Negeri 1 Bontonompo Kabupaten Gowa (Munirah 2017). Pada Penelitian ini, terdapat perbedaan yang signifikan antara kefektivan peserta didik menulis paragraf argumentasi dengan menerapkan strategi brainstorming dan yang menerapkan pembelajaran konvensional. Peningkatan Kemampuan Menulis Menggunakan Metode Sugestopedia pada Mahapeserta didik Program Studi Pendidikan Bahasa Indonesia Fakultas Keguruan dan Ilmu Pendidikan Universitas Bengkulu (Kurniawan dan Kartini 2019). Selanjutnya, Peningkatan Kualitas Pembelajaran Menulis melalui Penerapan Pendekatan Proses di Kelas V Sekolah Dasar. (Sumarwati, 2019).

Selain penelitian tersebut, penelitian lain tentang menulis seperti, Upaya Meningkatkan Kemampuan Menulis Teks Laporan Hasil Observasi melalui Penerapan Model Pembelajaran Problem Based Learning Pada Peserta Didik Kelas X Tiptl 1 SMK Negeri Sumsel (Elyana 2020). Selain itu, Penelitian berjudul Pengembangan Media Pembelajaran Menulis Teks Eksplanasi Berbasis Aplikasi Mindmap Peserta didik Kelas VIII SMP Negeri 33 Palembang (Marsela 2020). Selanjutnya penelitian yang spesifik pada menulis diskripsi berjudul Struktur dan Unsur Kebahasaan Teks Deskripsi Peserta didik Kelas VII SMP Negeri 30 Padang (Lusita dan Emidar 2019). Penelitian ini dalam bentuk penelitian kualitatif deskriptif dengan kesimpulan peserta didik dapat menulis teks deskripsi dengan menggunakan dua struktur dengan baik. Selanjutnya, Kemampuan Menulis Teks Deskripsi Berdasarkan Pengamatan Langsung Peserta didik Kelas VII SMP Negeri 3 Sungguminasa Kabupaten Gowa. (Jamal dkk., 2018)

Strategi Clustering adalah suatu cara memilah gagasan dan menuliskannya ke atas kertas secepatnya, tanpa melakukan pertimbangan. Clustering merupakan pemetaan pikiran sehingga menghasilkan penataan gagasan sebelum memulai menulis. Metode ini merupakan alat menulis yang bisa menerima rasa penasaran, ketidaktahuan serta sesuatu yang tampak kacau-balau, yang secara bertahap memetakan interior landscape seiring dengan timbulnnya gagasan (Hernacki dan Bobbi DePorter 2002: 180).

Metode Clustering bertujuan untuk merangsang gagasan-gagasan dalam suatu proyek penulisan yang sebenarnya. Teknik ini sangat ampuh karena dapat merangsang seseorang untuk bekerja secara alamiah dengan gagasan-gagasan tanpa harus 
menyunting. Selanjutnya, metode Show Not Tell akan menjadikan kalimat-kalimat hasil Clustering menjadi lebih deskriptif.

\section{Kerangka Teori}

Menulis Deskripsi

Dalam Kamus Besar Bahasa Indonesia V (2016), menulis berarti 1) membuat huruf (angka dan sebagainya) dengan pena (pensil, kapur, dan sebagainya), 2) melahirkan pikiran atau perasaan (seperti mengarang, membuat surat) dengan tulisan. Menulis dapat didefinisikan sebagai suatu kegiatan penyampaian pesan (komunikasi) dengan menggunakan bahasa tulis sebagai alat atau medianya. Menulis merupakan salah satu keterampilan berbahasa yang digunakan untuk berkomunikasi secara tidak langsung atau tidak bertatap muka dengan orang lain (Munirah, 2017 : 153)

Tulisan merupakan sebuah simbol atau lambang bahasa yang dapat dilihat dan disepakati pemakainya (Destiana, 2019): Selanjutnya, menulis adalah kegiatan mentransformasikan pikiran atau gagasan menjadi simbol-simbol yang dapat dibaca dan dipahami oleh orang lain (Heri, 2015 : 10). Menurut Tarigan (dalam Listya, 2018:4) menulis ialah menurunkan atau melukiskan lambang-lambang grafik yang menggambarkan suatu bahasa yang dipahami seseorang, sehingga orang lain dapat membaca lambang-lambang garfik tersebut kalau mereka memahami bahasa dan gambaran grafik itu.

\section{Metode Clustering (Pengelompokan)}

Clustering yang dikembangkan oleh Gabrielle Rico adalah suatu cara memilah pemikiran-pemikiran yang berkaitan dan menuangkannya di atas kertas secepatnya, tanpa mempertimbangkan kebenaran atau nilainnya (Hernacki, Bobbi DePorter 2002:180). Metode ini merupakan alat menulis yang bisa menerima rasa penasaran, ketidaktahuan serta sesuatu yang tampak kacau-balau yang secara bertahap memetakan interior landscape seiring dengan timbulnya gagasan." Metode Clustering sangat ampuh karena mampu membuat penulis menuangkan gagasan-gagasan dengan bekerja secara alamiah tanpa menyunting sama sekali.

\section{Show Not Tell (Menunjukkan bukan Memberitahukan)}

Show Not Tell dikembangkan oleh Rebekah Caplan. Sebuah kalimat deskripsi yang sebelumnya tidak mempunyai kekhasan diubah menjadi lebih deskriptif dan lebih hidup.Sebuah kalimat-kalimat pemberitahuan yang kering diubah menjadi deskripsi yang menakjubkan. Penerapan Show Not Tell akan menjadika tulisan lebih deskriptif dan menggugah.

\section{Metode}

\section{Jenis dan Desain Penelitian}

Dalam penelitian ini menggunakan jenis penelitian eksperimen dengan pendekatan kuantitatif. Metode eksperimen diartikan sebagai metode dengan bentuk yang sistematis dengan tujuan untuk mencari pengaruh variabel satu dengan variabel yang lain dengan memberikan perlakuan khusus dan pengendalian yang ketat dalam suatu kondisi.

Desain penelitian yang digunakan dalam penelitian ini adalah one group pretestposttest design yaitu desain penelitian yang diberi pretest sebelum diberikan perlakuan dan pemberian posttest setelah diberikan tindakan atau perlakuan. 


\section{Populasi dan Sampel}

Populasi

Populasi adalah keseluruhan subjek penelitian Arikunto (dalam Hatmoko, 2015:1731) Populasi dalam penelitian ini yakni 9 SMP Negeri di Kecamatan Binamu Kabupaten Jeneponto yang berjumlah 32 kelas.

Sampel

Sampel adalah subjek penelitian yang mewakili populasi. Melalui teknik cluster random sampling, dipilih 3 sekolah dengan 3 kelas sebagai sampel. Jumlah sampel, yakni 33 Peserta didik di SMPN 9 Binamu, 27 Peserta didik di SMPN 6 Binamu, dan 25 Peserta didik di SMPN 4 Binamu. Jadi, jumlah keseluruhan sampel pada 3 sekolah sebanyak 75 peserta didik.

\section{Metode Pengumpulan Data}

Pengumpulan data dilakukan dengan menggunakan penugasan menulis untuk mendapatkan hasil dan selanjutnya dianalisis. Hasil penugasan menulis inilah yang menjadi tes. Tes adalah pertanyaan untuk mengukur suatu keterampilan, pengetahuan, intelegensi. Arikunto(dalam Wibowo dan Suwardi 2017:313)

\section{Teknik Analisis Data}

Teknik analisis yang digunakan adalah deskriptif dan Uji hipotesis (uji t) model paired sampel test untuk melihat apakah terdapat perbedaan antara nilai hasil data sebelum dan sesudah perlakuan, sehingga dapat dinyatakan terdapat pengaruh atau tidaknya perlakuan tersebut. Pada analisis deskriptif kuantitatif, penentuan kemampuan menulis deskripsi menjadikan KKM rata-rata pada 3 sekolah sampel sebagai acuan. KKM rata-rata yang ditetapkan dari tiga sekolah sampel adalah 68.

\section{Hasil dan Pembahasan Hasil Penelitian}

Hasil pada penelitian ini dilihat dari distribusi frekuensi dan persentase nilai pretest dan post-test yang disajikan pada tabel di bawah ini:

Tabel 1. Distribus Frekuensi dan Persentase Nilai Pre-test.

\begin{tabular}{ccccc}
\hline Nilai & Frekuensi & Persentase & $\begin{array}{c}\text { Pesentase } \\
\text { Valid }\end{array}$ & $\begin{array}{c}\text { Persentase } \\
\text { Kumulatif }\end{array}$ \\
\hline 5,00 & 4 & 5,3 & 5,3 & 5,3 \\
\hline 8,00 & 1 & 1,3 & 5,3 & 6,7 \\
\hline 10,00 & 4 & 5,3 & 1,3 & 12,0 \\
\hline 12,00 & 1 & 1,3 & 2,7 & 13,3 \\
\hline 13,00 & 2 & 2,7 & 2,7 & 18,7 \\
\hline 14,00 & 2 & 2,7 & 1,3 & 20,0 \\
\hline 16,00 & 1 & 1,3 & 2,7 & 22,7 \\
\hline 22,00 & 2 & 2,7 & 1,3 & 24,0 \\
\hline 23,00 & 1 & 1,3 & 1,3 & 25,3 \\
\hline 24,00 & 1 & 1,3 & 10,7 & 36,0 \\
\hline 25,00 & 8 & 10,7 & 1,3 & 37,3 \\
\hline 26,00 & 1 & 1,3 & 4,0 & 41,3 \\
\hline 27,00 & 3 & 4,0 & 1,3 & 42,7 \\
\hline 28,00 & 1 & 1,3 & 1,3 & 44,0 \\
\hline 29,00 & 1 & 1,3 & 6,7 & 50,7 \\
\hline 30,00 & 5 & 6,7 & 2,7 & 53,3 \\
\hline 32,00 & 2 & 2,7 & 4,0 & 57,3 \\
\hline 35,00 & 3 & 4,0 & 6,7 & 64,0 \\
\hline 40,00 & 5 & 6,7 & &
\end{tabular}




\begin{tabular}{ccccc}
\hline 42,00 & 1 & 1,3 & 1,3 & 65,3 \\
\hline 45,00 & 2 & 2,7 & 2,7 & 68,0 \\
\hline 49,00 & 1 & 1,3 & 1,3 & 69,3 \\
\hline 50,00 & 7 & 9,3 & 9,3 & 78,7 \\
\hline 55,00 & 5 & 6,7 & 6,7 & 85,3 \\
\hline 60,00 & 4 & 5,3 & 5,3 & 90,7 \\
\hline 65,00 & 2 & 2,7 & 2,7 & 93,3 \\
\hline 70,00 & 2 & 2,7 & 2,7 & 96,0 \\
\hline 75,00 & 2 & 2,7 & 2,7 & 98,7 \\
\hline 82,00 & 1 & 1,3 & 1,3 & 100,0 \\
\hline Total & 75 & 100,0 & 100,0 & \\
\hline
\end{tabular}

Adapun data tersebut dapat dilihat dalam bentuk histogram berikut.

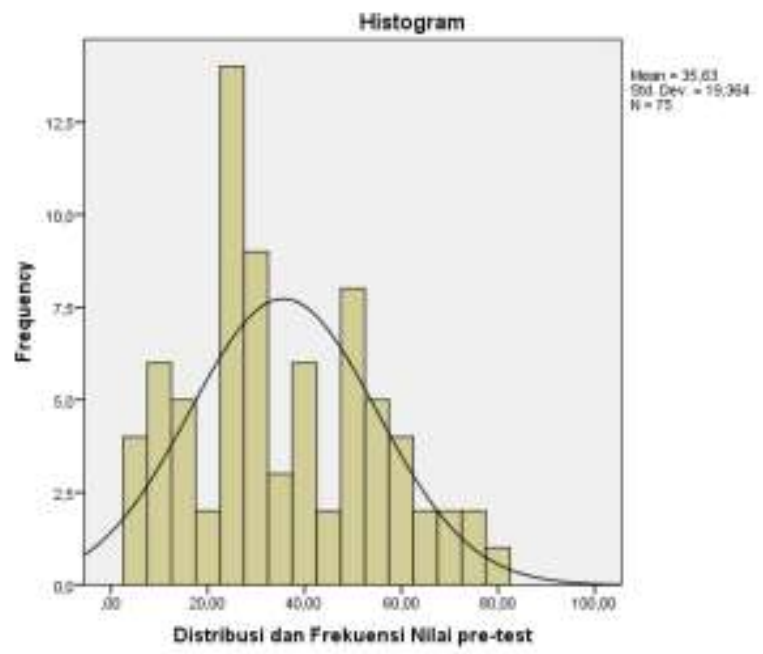

Gambar 1. Distribus Frekuensi dan Persentase Nilai Pre-test.

Adapun kategorisasi hasil kemampuan menulis teks deskripsi berdasarkan nilai pre-test dapat dilihat pada tabel berikut.

Tabel 2. Kategorisasi dan Frekuensi Hasil Kemampuan Menulis Teks Deskripsi Berdasarkan Nilai Pre-test

\begin{tabular}{cccccc}
\hline No & $\begin{array}{c}\text { Interval } \\
\text { Nilai }\end{array}$ & Kategori & Frekuensi & Presentase (\%) & $\begin{array}{c}\text { Rata- } \\
\text { Rata }\end{array}$ \\
\hline 1 & $85-100$ & Sangat Mampu & - & & \\
2 & $68-84$ & Mampu & 5 & 6,77 & 35,67 \\
3 & $\leq 67$ & Kurang Mampu & 70 & 93,33 & 100 \\
\hline \multicolumn{7}{c}{ Jumlah } & 75 & \\
\hline
\end{tabular}

Berdasarkan tabel tersebut, dapat digambarkan bahwa tidak seorang pun peserta didik yang memperoleh nilai dengan rentang 85-100 atau kategori sangat mampu. Sebanyak $5(6,77 \%)$ peserta didik yang masuk kategori mampu dan $70(9,33 \%)$ peserta didik dengan rentang nilai $\leq 67$ atau kategori kurang mampu. Berdasarkan nilai rata-rata pre-test, hasil kemampuan menulis teks deskripsi peserta didik berada pada kategori kurang mampu. 
ISSN 2443-3667 (print) 2715-4564 (online)

Tabel 3. Distribus Frekuensi dan Persentase Nilai Post-test

\begin{tabular}{|c|c|c|c|c|}
\hline Nilai & Frekuensi & Persentase & $\begin{array}{c}\text { Pesentase } \\
\text { Valid }\end{array}$ & $\begin{array}{l}\text { Persentase } \\
\text { Kumulatif }\end{array}$ \\
\hline 40,00 & 1 & 1,3 & 1,3 & 1,3 \\
\hline 42,00 & 3 & 4,0 & 4,0 & 5,3 \\
\hline 46,00 & 1 & 1,3 & 1,3 & 6,7 \\
\hline 50,00 & 1 & 1,3 & 1,3 & 8,0 \\
\hline 52,00 & 1 & 1,3 & 1,3 & 9,3 \\
\hline 55,00 & 3 & 4,0 & 4,0 & 13,3 \\
\hline 56,00 & 1 & 1,3 & 1,3 & 14,7 \\
\hline 62,00 & 3 & 4,0 & 4,0 & 18,7 \\
\hline 64,00 & 1 & 1,3 & 1,3 & 20,0 \\
\hline 65,00 & 1 & 1,3 & 1,3 & 21,3 \\
\hline 68,00 & 7 & 9,3 & 9,3 & 30,7 \\
\hline 70,00 & 3 & 4,0 & 4,0 & 34,7 \\
\hline 72,00 & 5 & 6,7 & 6,7 & 41,3 \\
\hline 74,00 & 5 & 6,7 & 6,7 & 48,0 \\
\hline 75,00 & 6 & 8,0 & 8,0 & 56,0 \\
\hline 76,00 & 4 & 5,3 & 5,3 & 61,3 \\
\hline 78,00 & 7 & 9,3 & 9,3 & 70,7 \\
\hline 79,00 & 3 & 4,0 & 4,0 & 74,7 \\
\hline 80,00 & 2 & 2,7 & 2,7 & 77,3 \\
\hline 82,00 & 4 & 5,3 & 5,3 & 82,7 \\
\hline 83,00 & 2 & 2,7 & 2,7 & 85,3 \\
\hline 85,00 & 5 & 6,7 & 6,7 & 92,0 \\
\hline 88,00 & 3 & 4,0 & 4,0 & 96,0 \\
\hline 90,00 & 2 & 2,7 & 2,7 & 98,7 \\
\hline 92,00 & 1 & 1,3 & 1,3 & 100,0 \\
\hline Total & 75 & 100,0 & 100,0 & \\
\hline
\end{tabular}

Berdasarkan data tersebut, dapat digambarkan dalam bentuk histogram berikut.

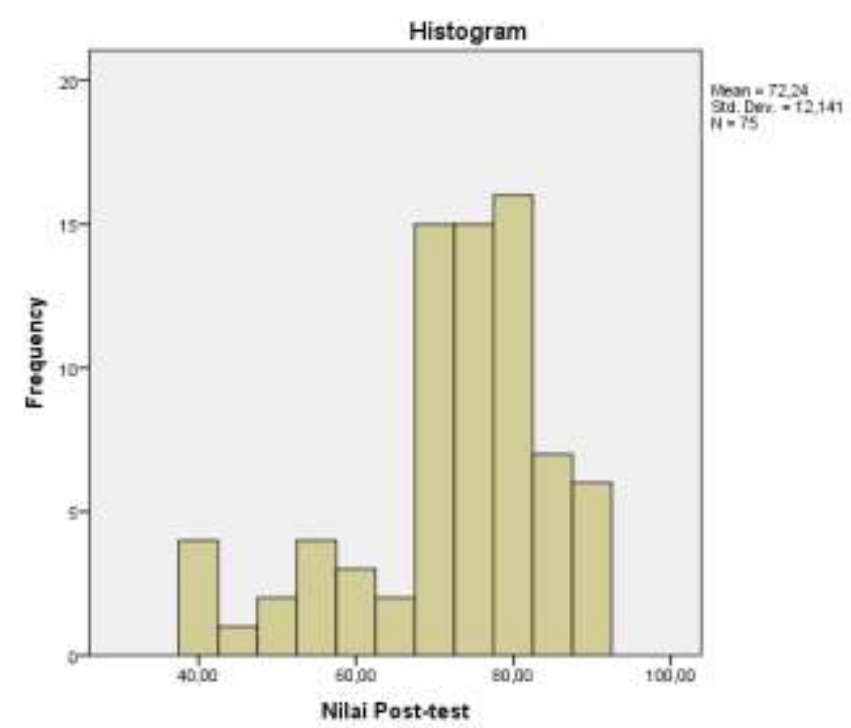

Gambar 2. Distribus Frekuensi dan Persentase Nilai Post-test

Adapun kategorisasi hasil kemampuan menulis teks deskripsi berdasarkan nilai post-test dapat dilihat pada tabel berikut. 
Tabel 4. Kategorisasi dan Persentase Hasil Menulis Teks Deskripsi Nilai Post-test

\begin{tabular}{|c|c|c|c|c|c|}
\hline No & Interval Nilai & Kategori & Frekuensi & Presentase (\%) & Rata-Rata \\
\hline 1 & $85-100$ & Sangat Mampu & 11 & 14,67 & \\
\hline 2 & $68-84$ & Mampu & 48 & 64 & 72,24 \\
\hline \multirow[t]{2}{*}{3} & $\leq 67$ & Kurang Mampu & 16 & 21,33 & \\
\hline & & Jumlah & 75 & 100 & \\
\hline
\end{tabular}

Berdasarkan tabel tersebut, dapat digambarkan bahwa peserta didik yang memperoleh nilai dengan rentang 85-100 atau kategori sangat mampu sebanyak 11 $(14,67 \%)$ orang. Sebanyak 48 (64\%) peserta didik yang masuk kategori mampu, dan 16 $(21,33 \%)$ peserta didik dengan rentang nilai $\leq 67$ atau kategori kurang mampu. Berdasarkan nilai rata-rata post-test, hasil kemampuan menulis teks deskripsi peserta didik berada pada kategori mampu.

\section{Pembahasan}

Analisis statistik deskriptif kuantitatif, hasil penilaian menulis teks deskripsi dengan metode show not tell dilihat nilai perolehan hasil belajar peserta didik dari 75 sampel sebesar 67,04. Nilai terendah yang diperoleh, yakni 38 dan nilai tertinggi sebesar 88. Ditinjau dari kualitas kemampuan menulis berdasarkan rata-rata yang diperoleh, nilai 67,04 berada pada interval 0-68 dengan kategori kurang mampu atau kurang 0,96 untuk dapat memenuhi KKM. Selanjutnya, jika dibandingkan dengan nilai rata-rata perolehan pre-test sebesar 35,62 terjadi peningkatan signifikan setelah menerapkan metode Show Not Tell menjadi 67,04 atau naik sebesar 31,42. Jika ditinjau dari KKM Mata pelajaran di tiga sekolah sampel sebesar 68, nilai rata-rata hasil penilaian menulis yang diperoleh peserta didik hampir mencapai nilai Kriterian Ketuntasan Minimum.

Pembelajaran menulis teks deskripsi dengan menerapkan metode Show Not Tell sebagai metode kedua dalam penelitian ini. Pembelajaran dimulai dengan mereview pemahaman peserta didik tentang teks deskripsi dan metode yang pernah dipelajari sebelumnya. Pembelajaran dilanjutkan dengan menguraikan metode, bentuk, dan pemberian contoh penerapan metode Show Not Tell dalam menulis. Pada tahapan ini peserta didik diberikan tema objek yang akan dideskripsikan sebagai tugas menulis.

Selanjutnya, peserta didik diarahkan untuk melakukan proses pendeskripsian dengan melibatkan segala potensi yang dimiliki dengan mengubah kalimat-kalimat biasa menjadi kalimat deskriptif. Berupaya mencari kosa kata yang lebih "hidup" atau lebih menunjukkan detail objek tanpa sekadar memberitahukan. Pada tahap perevisian, peserta didik diharapkan kembali memperhatikan strustur, organisasi karangan, dan penerapan EYD-nya.

Penerapan metode Show Not Tell dapat memberikan pengaruh signifikan terhadap kemampuan peserta didik dalam menulis teks deskripsi. Hal ini sesuai dengan pendapat Rebekah Caplan yang mengatakan bahwa Show Not Tell mengambil bentuk "kalimatkalimat pemberitahuan" kemudian mengubahnya menjadi "paragraf-paragraf yang menunjukkan". Sebuah kalimat deskripsi yang sebelumnya tidak mempunyai kekhasan diubah menjadi lebih deskriptif dan lebih hidup (Hernacki dan De porter, 2002:190). Perolehan nilai hasil belajar dengan Show Not Tell lebih baik dibandingkan dengan perolehan nilai dengan menggunakan metode Clustering. Metode Show Not Tell lebih memudahkan peserta didik mengembangkan ide atau gagasan menjadi lebih panjang. 
Metode ini lebih memudahkan peserta didik mendeskripsikan objek dengan pelibatan pancaindera dalam penggambaran.

Penerapan metode Show Not Tell efektif terhadap peningkatan nilai rata-rata hasil menulis teks deskripsi peserta didik SMP kelas VII di Kecamatan Binamu ditandai dengan peningkatan nilai rata-rata perolehan, dan signifikan dalam pencapaian ketuntasan belajar berdasarkan Kriteria Ketuntasan Minimal. Selanjutnya, Kemampuan menulis teks deskripsi dengan menerapkan metode Clustering dan Show Not Tell diukur dengan membandingkan hasil penilaian menulis pada pre-test dan post-test dengan analisis deskriptif kuantitatif dan uji hipotesis. Uji hipotesis dilakukan dengan menggunakan uji $t$ model pairet sampel test. Dari pengujian yang dilakukan pada 75 sampel, diperoleh data hasil penilaian menulis dengan nilai rata-rata pada pre-test, yakni 35,62 dengan standar deviasi 19,36.

Penilaian pre-test dilakukan di awal pembelajaran pada kelas sampel. Sebelum penilain pre-test, peserta didik diberikan penjelasan tentang menulis teks deskripsi dan menggali pengetahuan peserta didik tentang teks deskripsi berdasarkan materi yang telah dipelajari sebelumnya. Langkah selanjutnya, peserta didik diminta menulis teks deskripsi tentang lingkungan sekolah sesuai dengan pemahaman yang dimiliki.

Selanjutnya, penilaian post-test dilakukan setelah peserta didik mempelajari dan memperaktikkan metode Clustering dan Show Not Tell. Kedua metode ini diterapakan pada waktu yang berbeda dan setiap selesai penerapan metode dan latihan diberikan penugasan penilaian menulis. Selanjutnya, post-test diberikan dengan menerapkan kedua metode tersebut secara bersamaan.

Pada post-test diperoleh nilai rata-rata 72,24 dengan standar deviasi 12,14. Berdasarkan pengujian tersebut dengan membandingkan nilai rata-rata pre-test dan posttest diketahui terdapat peningkatan signifikan sebesar 36,62 sehingga diketahui terdapat peningkatan nilai rata-rata hasil menulis antara sebelum dan setelah menerapkan metode Clustering dan Show Not Tell.

Secara deskriptif kuantitati maupun dengan menggunakan uji $t$ dengan menggunakan model paired sampel test dengan kriteria yang digunakan dalam uji paired sampel test adalah jika nilai sig. ( 2 tailed) $<0,05$, disimpulkan bahwa terdapat perbedaan signifikan antara hasil penilaian pada data pre-test dan post-test atau tidak terdapat perbedaan signifikan jika nilai sig. (2 tailed) $>0,05$.

Dari hasil uji yang dilakukan, diketahui bahwa nilai sig. (2 tailed) sebesar 0,000 yang berati bahwa hasil tersebut $\alpha<0,05$. Berdasarkan data tersebut, disimpulkan bahwa penerapan metode Clustering dan Show Not Tell efektif meningkatkan kemampuan menulis teks deskripsi peserta didik SMP Kelas VII di Kecamatan Binamu.

Hasil penenelitian tersebut menunjukkan bahwa dengan menerapkan metode Clustering dan Show Not Tell efektif dalam meningkatkan nilai perolehan menulis teks deskripsi peserta didik SMP Kelas VII di Kecamatan Binamu. Metode Clustering akan membantu peserta didik dalam memetakan pikiran dan mengungkapkan gagasan secara secara cepat dan menuangkannnya ke atas kertas tanpa mempertimbangkan kebenaran atau nilainya (Hernacki dan De porter, 2002:180).

Selanjutnya, hasil curahan ide dan gagasan tersebut dikembangkan dengan menggunakan Show Not Tell. Langkah ini yang akan membantu peserta didik dalam mengembangkan kalimat-kalimat sederhana menjadi lebih deskriptif atau Rebeca Caplan mengatakan bahwa kalimat-kalimat pemeritahuan menagubah menjadi paragraph. (Hernacki dan De porter, 2002:180). Hal ini terbukti seperti yang terlihat saat penugasan menulis di post-test, dengan menerapkan metode Show Not Tell, peserta didik menjadi lebih mudah mengurai bagian-bagian kalimat yang berupa benda atau objek tertentu 
menjadi lebih detail sehingga membantu peserta didik dalam mengembangkan teks deskripsi yang disusunnya. Hala ini sama dengan pendapat Kosasih (dalam Permanasari, 2017:158) bahwa karangan deskripsi adalah karangan yang menggambarkan suatu objek dengan tujuan agar pembaca merasa seolah-olah melihat sendiri objek yang digambarkan itu. Selanjutnya, dengan Show Not Tell, Ide atau gagasan lebih mudah dikembangkan dan peserta didik lebih mudah menentukan kata atau objek yang akan dideskripsikan. Hal ini juga sejalan dengan pendapat Alwasilah (dalam Rahayu 2017:161), yang mengatakan bahwa deskripsi adalah gambaran verbal ihwal manusia, objek, penampilan, pemandangan, atau kejadian sehingga dengan cara ini, pembacanya seolah-olah melihat langsung peristiwa tersebut.

\section{Simpulan}

1. Kemampuan menulis teks deskripsi peserta didik SMP kelas VII di Kecamatan Binamu dengan menggunakan metode Clustering meningkat ditandai dengan peningkatan nilai rata-rata perolehan dari 35,62 pada pre-test menjadi 46,65 , tetapi tidak pencapaian ketuntasan belajar berdasarkan Kriteria Ketuntasan Minimal dibuktikan dengan perolehan nilai rata-rata sebesar 46,65. Nilai tersebut belum memenuhi kriteria ketuntasan, yakni nilai 68.

2. Kemampuan menulis teks deskripsi peserta didik SMP kelas VII di Kecamatan Binamu dengan menggunakana metode Show Not Tell meningkat ditandai dengan peningkatan nilai rata-rata perolehan dari 35,62 pada pre-test menjadi 67,04. Nilai ini kurang 0,98 untuk mencapai ketuntasan minimal, yakni 68.

3. Metode Clustering dan Show Not Tell efektif terhadap kemampuan menulis deskriptif peserta didik SMP kelas VII di Kecamatan Binamu Hal ini dibuktikan dengan kenaikan rata-rata perolehan peserta didik dari nilai pre-test, yakni 35,62 naik menjadi 72,24 pada post-test. Demikian halnya dengan pengujian hipotesis menggunakan uji $t$ dengan menggunakan model paired sampel test dengan kriteria yang digunakan jika nilai sig. ( 2 tailed) $<0,05$ disimpulkan efektif. Dalam penelitian ini diketahui nilai sig. ( 2 tailed) sebesar 0,000 atau $\alpha<0,05$ sehingga penggunaan metode Clustering dan Show Not Tell efektif meningkatkan kemampuan menulis teks deskripsi peserta didik SMP Kelas VII di Kecamatan Binamu.

\section{Ucapan Terima Kasih}




\section{Daftar Pustaka}

Asniar. 2019. "Peningkatan Kemampuan Anak Menulis Kalimat Tegak Bersambung Melalui Metode Latihan di Kelas II SD Inpres 3 Bolapapu." Jurnal Kreatif Online, Vol. 7 No. 2 ISSN 2354-614X 7(2):13.

Azis, Sitti Aida, dan Aziz Thaba. 2021. "Peningkatan Kemampuan Menulis Cerita Pendek melalui Penerapan Metode Partisipatoris Siswa VII F SMPN 3 MAKASSAR.” KREDO : Jurnal Ilmiah Bahasa dan Sastra 4(2):329-48.

Destiana, F. Donna. 2019. Keterampilan Berbahasa Menulis Karangan Deskripsi. Surakarta.

Destiana, Nadhira. 2013. "Pembelajaran Menulis Karangan Argumentasi Melalui Pemanfaatan Tayangan Editorial Media Indonesia Di Metro TV (Penelitian Eksperimen Semu terhadap Siswa Kelas X SMAN 2 Bandung." Universitas Pendidikan Indonesia, Bandung.

Elyana, Latifah Ratnawati dan Sri. 2020. “Upaya Meningkatkan Kemampuan Menulis Teks Laporan Hasil Observasi melalui Penerapan Model Pembelajaran Problem Based Learning pada Peserta Didik Kelas X TIPTL 1 SMK Negeri Sumsel." Logat: Jurnal Bahasa Indonesia dan Pembelajaran 7(2):112-22.

Febrianti dkk. 2020. "Komparasi Keterampilan Menulis Teks Deskripsi dengan Keterampilan Menulis Teks Cerita Fantasi Siswa Kelas VII SMP Negeri 7 Padang." Pendidikan Bahasa Indonesia 9(3):72.

Hatmoko, Jefri Hendri. 2015. "Survey Minat dan Motivasi Siswa Putri terhadap Mata Pelajaran Penjasorkes di SMK Se-Kota Salatiga Tahun 2013." Journal of Physical Education, Sport, Health and Recreation 4(2):102-8.

Helti, Mezri. 2014. "Peningkatan Keterampilan Menulis Karangan Eksposisi dengan Menggunakan Model Pembelajaran Kooperatif Tipe CIRC Siswa Kelas XI SMK Karya Padang Panjang." Universitas Negeri Padang.

Heri, Susanto. 2015. "Peningkatan Keterampilan Menulis Karangan Narasi Menggunakan Media Gambar Berseri Siswa Kelas V SD N 3 Bondolharjo Banjar Negara." Universitas Negeri Yogyakarta.

Hernacki, Bobbi DePorter, dan Mike. 2002. “Quantum Learning.” : 356 in. Bandung: Kaifa.

Jamal, Sherlina, Syamsuddha, dan M. Taufik. 2018. “Kemampuan Menulis Teks Deskripsi Berdasarkan Pengamatan Langsung Kelas VII SMP Negeri 3 Dungguminasa Kabupaten Gowa." Jurnal Pendidikan Bahasa dan Sastra Indonesia 3(1):1-12.

Kurniawan, Rio, dan Kartini Kartini. 2019. "Peningkatan Kemampuan Menulis Menggunakan Metode Sugestopedia pada Mahasiswa Program Studi Pendidikan Bahasa Indonesia Fakultas Keguruan dan Ilmu Pendidikan Universitas Bengkulu." ESTETIK: Jurnal Bahasa Indonesia 2(1):33. doi: 10.29240/estetik.v2i01.892. 
Lestari, Oktavia Winda. 2020. "ANALISIS KESALAHAN MENULIS TEKS DESKRIPSI SISWA MATHAYOM IV-3 MUSLIM SANTITHAM FOUNDATION SCHOOL THAILAND.” IAIN Tulung Agung.

Lestari, Sri. 2009. “Upaya Meningkatkan Keterampilan Menulis Siswa Dengan Pendekatan Kontekstual."

Listya, Eka dkk. 2018. "Pemanfaatan buku pelajaran bahasa indonesia sebagai sumber belajar dalam pembelajaran menulis di kelas xi." 1-14.

Lusita, Juvira, dan Emidar. 2019. "Struktur Dan Unsur Kebahasaan Teks Deskripsi Siswa Kelas Vii Smp Negeri 30 Padang." Jurnal Pendidikan Bahasa dan Sastra Indonesia 8(1):113-20.

Marsela, Vitria dan Supriyadi. 2020. "Pengembangan Media Pembelajaran Menulis Teks Eksplanasi Berbasis Aplikasi Mindmap Siswa Kelas VIII SMP Negeri 33 Palembang." Logat, Volume 7, No 2, November 2020 21(1):1-9.

Mu'minin Nurul. 2018. “Efektivitas Penggunaan Media Quantum Teaching dalam Pembelajaran Menulis Puisi pada Siswa Kelas XII Madrasah Aliyah Negeri (MAN) Wajo Kabupaten Wajo.Tesis." Universitas Muhammadiyah Makassar.

Munirah. 2017. "Keefektivan Strategi Brainstorming Dalam Pembelajaran Menulis Paragraf Argumentasi Siswa Kelas Xi Sma Negeri 1 Bontonompo Kabupaten Gowa." Konfiks : Jurnal Bahasa Dan Sastra Indonesia 2(2):152. doi: 10.26618/jk.v2i2.415.

Munirah, Munirah, R. Asmara, dan W. Kusumaningrum. 2019. "Cooperative Learning Model of P2RE type on Paragraph Writing Skills.” (April). doi: 10.4108/eai.21-122018.2282736.

Naki dkk. 2018. "Deskripsi dalam Bahasa Indonesia melalui Media Gambar Seri pada Siswa Kelas VII SMPN 18." Ilmu Budaya 6(2):1-9.

Nurasiah, Desi, Emah Khuzaemah, dan Indrya Mulyaningsih. 2020. "Pengembangan Media Pembelajaran Menulis Teks Ceramah Berbasis Internet Bagi Siswa Kelas XI." ESTETIK: Jurnal Bahasa Indonesia 3(2):2622-1829. doi: 10.29240/estetik.v3i2.1756.

Permanasari, Dian. 2017. "Kemampuan Menulis Teks Deskripsi Siswa Kelas VII SMP Negeri 1 Sumber Jaya Lampung Barat." Jurnal Pesona 3(2):156-62. doi: 10.26638/jp.444.2080.

Prihatiningrum Ikha Anggraeni, Dkk. 2017. "Peningkatan Kemampuan Menulis Paragraf Deskripsi Ragam Krama melalui Metode Pemodelan dan Media Gambar Tematik pada Siswa Kelas X IIS 2 SMA." Jurnal Sabdasastra Vol. 3(1) ISSN: 2620-343X 3(1):117-31.

Qalsum, Ummu. 2014. "Penggunaan Metode Bermain Peran ( Role Playing ) Untuk Meningkatkan Keterampilan Menulis Deskripsi Pada Siswa." : 10 in Prosiding Seminar Nasional Pendidikan Karakter 2014. Vol. 01. Palopo. 
Rahayu, Yanti Sri. 2016. "Penerapan Model Sinektik Berorientasi Berpikir Kreatif dalam Pembelajaran Menulis Teks Deskripsi Siswa SMP.” Universitas Pasundan.

Rahayu, Yanti Sri. 2017. "Penerapan Model Sinektik Berorientasi Berpikir Kreatif dalam Pembelajaran Menulis Teks Deskripsi Siswa SMP." LITERASI, Jurnal Ilmiah Pend. Bahasa, Sastra Indonesia dan Daerah, Vol.7, No.2, Juli 2017 7(2):160-70.

Sianti, Midin. 2015. "Peningkatan Kemampuan Menulis Laporan dalam Bentuk Karangan Deskripsi Siswa Kelas XII IPA 3 SMA Negeri 2 Palopo melalui Penerapan Strategi Neighborhood Walk Midin." Jurnal Pendidikan, Pengajaran Bahasa dan Sastra ONOMA PBSI FKIP Universitas Cokroaminoto Palopo Peningkatan 151:10-17.

Sumarwati. 2019. "Peningkatan Kualitas Pembelajaran Menulis melalui Penerapan Pendekatan Proses di Kelas V Sekolah Dasar." Logat: Jurnal Bahasa Indonesia dan Pembelajaran 6(2):151-67.

Supriyadi. 2018. Keterampilan Dasar Menulis. Gorontallo: Ideas Publishing.

Wibowo dan Suwardi. 2017. "Penilaian Kemampuan Menulis Karangan Deskriptif Siswa Sekolah Dasar." Jurnal Gentala Pendidikan Dasar 2(2):310-28. doi: 10.22437/gentala.v2i2.6813. 